\title{
Low Temperature Direct Conversion of Methane using a Solid Superacid
}

\author{
Swarom Kanitkar, ${ }^{[a]}$ James H. Carter, ${ }^{[b]}$ Graham J. Hutchings, ${ }^{[a, b]}$ Kunlun Ding, ${ }^{[a]}$ James J Spivey, ${ }^{* a]}$
}

Abstract: The direct conversion of methane to higher hydrocarbons and hydrogen can be catalyzed using "superacids":

$$
n \mathrm{CH}_{4} \stackrel{\text { superacid }}{\longrightarrow} \mathrm{C}_{n} \mathrm{H}_{m}+x \mathrm{H}_{2}
$$

The first report of catalytic oligomerization of methane using superacids was that of Olah et al., who demonstrated the superacidity of $\mathrm{FSO}_{3} \mathrm{H}-\mathrm{SbF}_{5}$, which is a liquid. More recently, Vasireddy et al. showed that gas-phase $\mathrm{HBr} / \mathrm{AlBr}_{3}$ was an active superacid. The only reported solid superacid for methane oligomerization is sulfated zirconia (SZ). Here, we report a new class of Br-based solid superacids, $A \mid B r_{x} / H-Z S M-5$ ("ABZ-5", $x=1$ or 2 ). $A B Z-5$ is based on gas-phase $\mathrm{HBr} / \mathrm{AlBr}_{3}$, with the objective of synthesizing a heterogeneous analogue of the gas-phase superacid $\mathrm{HBr} / \mathrm{AlBr}_{3}$. The results show that ABZ-5 is significantly more active than SZ. Perhaps more significantly, results here show methane conversions of $\sim 1 \%$ at $300^{\circ} \mathrm{C}$ using ABZ-5. By comparison with $\mathrm{SZ}, 350^{\circ} \mathrm{C}$ is the lowest temperature reported in the literature at which measureable conversions are shown, and the corresponding methane conversions were $<0.15$. Here, we demonstrate direct conversion of methane using a solid superacid catalyst, $\mathrm{AlBr}_{x} / \mathrm{H}-\mathrm{ZSM}-5$. This solid catalyst is synthesized using a vapor-phase process in which $\mathrm{AlBr}_{3}$ vapor is grafted on to solid H-SZM-5. This catalyst is characterized using $\mathrm{NH}_{3}$ TPD, XRD, and DRIFTS. Hydrocarbon products observed in the temperature range of $200-400^{\circ} \mathrm{C}$ include both $\mathrm{C}_{2}-\mathrm{C}_{6}$ hydrocarbons and aromatics.

\section{Introduction}

Methane conversion to higher-value products has been a topic of research for decades, but the "shale gas revolution" has made low-cost natural gas readily available. This has presented a unique opportunity to take advantage of the immense, previously inaccessible reserves of natural gas. This has already had major impacts on the energy and chemical industries ${ }^{[1]}$.

Methane is a thermodynamically stable, non-polar molecule containing strong, equivalent $(\mathrm{C}-\mathrm{H})$ bonds $(434 \mathrm{~kJ} / \mathrm{mol}){ }^{[2]}$. Activation of methane typically requires very high temperatures and oxidants like $\mathrm{O}_{2}$ (partial oxidation/oxidative coupling) ${ }^{[3]}$,

[a] M.S.-Chem. Eng., S. Kanitkar, Dr. K. Ding, Dr. J. J. Spivey, Dr. G. Hutchings

Cain Department of Chemical Engineering

Louisiana State University

Baton Rouge, LA - 70803, USA

E-mail: jispivey@lsu.edu

[b] Dr. J. Carter, Dr. G. Hutchings

Cardiff Catalysis Institute

Cardiff University

Cardiff, UK CF10 3AT

Supporting information for this article is given via a link at the end of the document.
$\mathrm{CO}_{2} / \mathrm{H}_{2} \mathrm{O}$ (reforming) ${ }^{[4]}, \mathrm{S}_{2}$ (sulfidation) ${ }^{[5]}$, or $\mathrm{Br}_{2}$ (bromination) ${ }^{[6]}$. These reactions produce intermediates like syngas or $\mathrm{CH}_{3} \mathrm{OH} / \mathrm{CH}_{3} \mathrm{SH} / \mathrm{CH}_{3} \mathrm{Br}$, which are subsequently converted into hydrocarbons or oxygenates. In these reactions, methane activation at elevated temperatures leads to another challenge: complete dehydrogenation of methane into elemental carbon or coke.

Direct (non-oxidative) conversion of methane is an alternative to processes that require intermediates such as syngas. Catalysts involving direct conversion include latticeconfined single Fe sites ${ }^{[7]}$ or modified-zeolites ${ }^{[8]}$ at very high temperatures $\left(700-1100^{\circ} \mathrm{C}\right)$. One particularly promising approach for the direct conversion of methane at lower temperatures is based on superacids (Figure 1). These catalysts were first demonstrated by Olah [9], using liquid "magic acid" $\left(\mathrm{FSO}_{3} \mathrm{H}-\mathrm{SbF}_{5}\right)$. Other superacids have been reported for the oligomerization of methane: $\left(\mathrm{SbF}_{5}-\mathrm{HF}\right)^{[10]},\left(\mathrm{HBr}^{\left.-\mathrm{AlBr}_{3}\right)}{ }^{[11]}\right.$, and sulfated zirconia ${ }^{[12]}$.

$\mathrm{HBr}-\mathrm{AlBr}_{3}$ is a particularly promising gas-phase superacid catalyst.

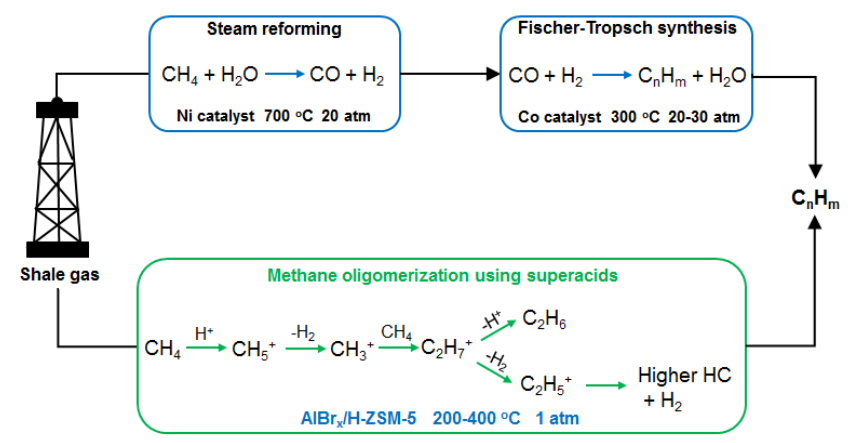

Figure 1. Current and proposed process for converting methane into olefins and fuels. At present, methane is reformed into syngas and then transformed into higher hydrocarbons through the Fischer-Tropsch synthesis. This indirect process requires high temperatures and pressures. Methane oligomerization using solid superacids offers a direct route to converting methane into higher hydrocarbons under mild conditions.

This is a proven strong superacid, and has been compared to the strongest known superacid, "magic acid" [13]. Recently [11b], this gas-phase superacid has been shown to convert $\mathrm{CH}_{4}$ into higher hydrocarbons $\left(\mathrm{C}_{2}-\mathrm{C}_{26}\right)$ and $\mathrm{H}_{2}$ at temperatures as low as 200$400^{\circ} \mathrm{C}$. Although $\mathrm{CH}_{4}$ conversions were relatively high, separating the catalyst from the gaseous products was difficult, making it practically impossible to carry out a carbon balance, or to envision a practical process based on a gas-phase superacid. This could be addressed by incorporating the proven gaseous $\mathrm{HBr}-\mathrm{AlBr}_{3}$ superacid onto a solid support.

Any process based on direct conversion of methane using superacids at the temperatures reported here $\left(200-400^{\circ} \mathrm{C}\right)$ must address the equilibria limitations. At the conditions of interest here, equilibrium methane conversion is 0.5 to $12 \%$ (with coke formation allowed) depending on the product composition, including hydrogen, alkanes/alkenes, polynuclear aromatics, 
among others. It is outside the scope of our study here to determine if a feasible process based on superacid catalysis of methane oligomerization is practical. However, we recognize that a solid superacid could be an essential element of a practical process.

We are aware of no report of a solid superacid based on bromine for methane oligomerization, despite the potential significance of an active solid superacid based on the gas-phase $\mathrm{HBr} / \mathrm{AlBr}_{3}$ catalyst sites. Our study here describes the synthesis, characterization and direct conversion of methane to higher hydrocarbons using a solid superacid, $\mathrm{AlBr}_{x} / \mathrm{H}-\mathrm{ZSM}-5$ ("ABZ-5", $\mathrm{x}$ $=1$ or 2). Though the oligomerization of methane is the focus here there are clear significant opportunities in related acid-catalyzed processes, e.g. alkylations and acylations [14]; alkane isomerization and cracking [14c, 15]; and polymerization ${ }^{[14 c]}$.

\section{Results and Discussion}

\section{Comparison with previous research}

Table 1 compares the literature on direct conversion of methane using solid superacids with a representative result on ABZ-5 reported here $\left(300^{\circ} \mathrm{C}\right)$.

Table 1. Comparison of performance of ABZ-5 with other solid superacids

\begin{tabular}{|c|c|c|c|c|c|}
\hline Catalyst & $\begin{array}{l}\text { Temp }{ }^{[\mathrm{a}]} \\
\left({ }^{\circ} \mathrm{C}\right)\end{array}$ & $\begin{array}{l}\text { Space } \\
\text { velocity } \\
g_{\left.\text {cat }^{-1} h^{-1}\right)}\end{array}$ & (L Conv. (\%) & Notes & Ref. \\
\hline $\mathrm{SZ} / \mathrm{Fe} / \mathrm{Mn}$ & $350-450$ & 0.76 & $<0.15$ & Flow reactor & {$[12 b]$} \\
\hline $\mathrm{SZ} / \mathrm{Fe} / \mathrm{Mn}^{[\mathrm{c}]}$ & 450 & 4.5 & $\mathrm{NR}^{*}$ & $\begin{array}{l}\text { Pulsed and } \\
\text { flow exp. }\end{array}$ & {$[16]$} \\
\hline $\mathrm{SZ} / \mathrm{Co} / \mathrm{Mn}^{[\mathrm{c}]}$ & 450 & 4.5 & NR & $\begin{array}{l}\text { Pulsed and } \\
\text { flow exp. }\end{array}$ & {$[16]$} \\
\hline $\mathrm{SZ} / \mathrm{Cu}^{[\mathrm{c}]}$ & 450 & 4.5 & NR & $\begin{array}{l}\text { Pulsed and } \\
\text { flow exp. }\end{array}$ & {$[16]$} \\
\hline $\mathrm{SZ} / \mathrm{Ni}^{[\mathrm{c}]}$ & 450 & 4.5 & NR & $\begin{array}{l}\text { Pulsed and } \\
\text { flow exp. }\end{array}$ & {$[16]$} \\
\hline $\mathrm{SZ} / \mathrm{Al}_{2} \mathrm{O}_{3}{ }^{[\mathrm{c}]}$ & 450 & 4.5 & NR & $\begin{array}{l}\text { Pulsed and } \\
\text { flow exp. }\end{array}$ & {$[16]$} \\
\hline$S Z^{[d]}$ & 400 & 0.6 & $\begin{array}{l}0.35 \text { after } \\
5 \mathrm{~h}\end{array}$ & $\begin{array}{c}\text { recirculating } \\
\text { reactor }\end{array}$ & {$[17]$} \\
\hline $\mathrm{SZ} / \mathrm{Al}_{2} \mathrm{O}_{3}{ }^{[\mathrm{d}]}$ & 400 & 0.6 & $\begin{array}{l}1.9 \text { after } 5 \\
h\end{array}$ & $\begin{array}{l}\text { recirculating } \\
\text { reactor }\end{array}$ & {$[17]$} \\
\hline$A B Z-5$ & 300 & 18 & $\sim 1$ & $\begin{array}{c}\text { Fixed bed } \\
\text { reactor }\end{array}$ & $\begin{array}{l}\text { Current } \\
\text { Work }\end{array}$ \\
\hline
\end{tabular}

Table 1 shows that methane conversions in the literature are not typically given. For studies in which conversions are reported, values vary from $0.15-1.9 \%$. However, a direct comparison of $\sim 1 \%$ conversion for the ABZ-5 catalyst with the literature is not possible because of the different reaction conditions. For example, Table 1 shows that results for ABZ- 5 at the temperature of $300^{\circ} \mathrm{C}$, while reported studies were carried out at higher temperatures, $350-450{ }^{\circ} \mathrm{C}$. SV values in the literature were $0.44-4.5 \mathrm{~L} \mathrm{~g}_{\mathrm{cat}}{ }^{-1} \mathrm{~h}^{-1}$, while here the space velocity was $18 \mathrm{~L} \mathrm{~g}_{\mathrm{cat}}^{-1} \mathrm{~h}^{-1}$, a factor of 4-40 times greater than those reported here. Table 1 suggests that
ABZ-5 is more active than SZ. In order to test this, a direct comparison was carried out.

\section{Direct comparison of ABZ-5 with other solid superacids}

Table 2 directly compares the activity of four solid superacids in $\mathrm{CH}_{4}$ oligomerization at identical conditions: H-ZSM-5 (asreceived), and three catalysts synthesized here (SI (supplementary information), 1.2): sulfated zirconia (SZ), $\mathrm{AlBr}_{3}$ supported on $\mathrm{SiO}_{2}(\mathrm{ABSi})$ and $\mathrm{AlBr}_{3}$ supported on ZSM-5 (ABZ-5). An intermediate temperature of $300^{\circ} \mathrm{C}$ was selected to compare solid superacid product selectivities directly.

Table 2. Time on stream (TOS) activity of ABZ-5 catalyst and its comparison against various catalysts for $\mathrm{CH}_{4}$ oligomerization $\left(300{ }^{\circ} \mathrm{C}\right.$, 1 atm, $9 \mathrm{Lgcat}^{-1} \mathrm{~h}^{-1}$, $\mathrm{CH}_{4}$ conv. 1\% for $\mathrm{ABZ}-5$ )

\begin{tabular}{|c|c|c|c|c|c|c|c|c|c|}
\hline \multirow[b]{2}{*}{ Cat. } & \multirow[b]{2}{*}{$\begin{array}{c}\text { TOS } \\
(\mathrm{hr})\end{array}$} & \multirow[b]{2}{*}{$\begin{array}{l}\text { TOF } \\
\left(\mathrm{hr}^{-1}\right)\end{array}$} & \multicolumn{7}{|c|}{ Product Selectivity $(\%)^{[\mathrm{e}]}$} \\
\hline & & & $\mathrm{C}_{2}=$ & $\mathrm{C}_{3}$ & $\mathrm{C}_{4}$ & $\mathrm{~B}^{[\mathrm{a}]}$ & $T^{[b]}$ & $\mathrm{EB}^{[\mathrm{c}]}$ & $\begin{array}{c}x \\
(o, m \\
, p)^{[d]}\end{array}$ \\
\hline ABZ-5 & 1 & 0.1 & 3.0 & 7.9 & 2.3 & 0.5 & 18.5 & 59.6 & 8.1 \\
\hline$A B Z-5$ & 2 & 0.015 & 8.2 & 14.9 & - & - & 26.1 & 41.3 & 9.5 \\
\hline$A B Z-5$ & 3 & 0.004 & 13.5 & 17.8 & - & - & 38 & - & 30.6 \\
\hline $\begin{array}{c}\text { Blank } \\
\text { (Quartz } \\
\text { Wool) }\end{array}$ & 1 & 0 & - & - & - & - & - & - & - \\
\hline ABSi & 1 & 0 & - & - & - & - & - & - & - \\
\hline $\begin{array}{c}\mathrm{H}- \\
\text { ZSM-5 }\end{array}$ & 1 & 0 & - & - & - & - & - & - & - \\
\hline SZ & 1 & 0 & - & - & - & - & - & - & - \\
\hline
\end{tabular}

[a] Benzene [b] Toluene [c] Ethylbenzene [d] Xylene (ortho, meta, para) [e]Selectivity is calculated based on total number of observed products. $(-)=$ not detected

Table 2 shows that only ABZ-5 is active, while there are no measurable products from any of the other catalysts at these conditions. A decrease in TOF (turnover frequency) with TOS (time on stream) for ABZ-5 indicates deactivation. With time, there is a general increase in ethylene and propane selectivity. Selectivity to aromatics is significant, even when methane conversion is $\sim 1 \%$. The aromatic selectivity also changes onstream: after $1 \mathrm{~h}$, ethylbenzene and toluene are the major products, but after $3 \mathrm{~h}$, no ethyl benzene was observed and the selectivity to xylene and toluene increased significantly.

Despite low methane conversions, these results provide clear evidence of methane activation at temperatures as low as $300{ }^{\circ} \mathrm{C}$ and demonstrates that ABZ-5 is a strong solid superacid.

\section{Acidity measurements}


The acidity of these superacids was characterized using pyridineDRIFTS, and $\mathrm{NH}_{3}$-TPD (Figure 2) and the crystallinity was characterized using XRD (SI, Figure S3). Pyridine-DRIFTS uses pyridine as a probe molecule to identify Brønsted and Lewis acid sites. Figure 2[a] compares the IR spectra of H-ZSM-5 and ABZ5 catalysts, which shows the effect on the IR spectra when $\mathrm{AlBr}_{3}$ is added to $\mathrm{H}-\mathrm{ZSM}-5$.

Figure 2. [a] Comparison of DRIFTS spectra at $300{ }^{\circ} \mathrm{C}$ for (a) Fresh ABZ-5, (b) H-ZSM-5, and (c) Spent ABZ-5. Region corresponding to $(L)=$ Lewis acid sites, (B) = Brønsted acid sites; [b] NH $H_{3}$-TPD for (a) Fresh ABZ-5, (b) H-ZSM-5, and (c) Spent ABZ-5.

*Spent catalyst refers to ABZ-5 recovered after $\mathrm{CH}_{4}$ oligomerization reaction ran at $300^{\circ} \mathrm{C}, 1 \mathrm{~atm}$, and $9 \mathrm{~L} . g c a t^{-1} \mathrm{hr}^{-1}$ for $16 \mathrm{hrs}$
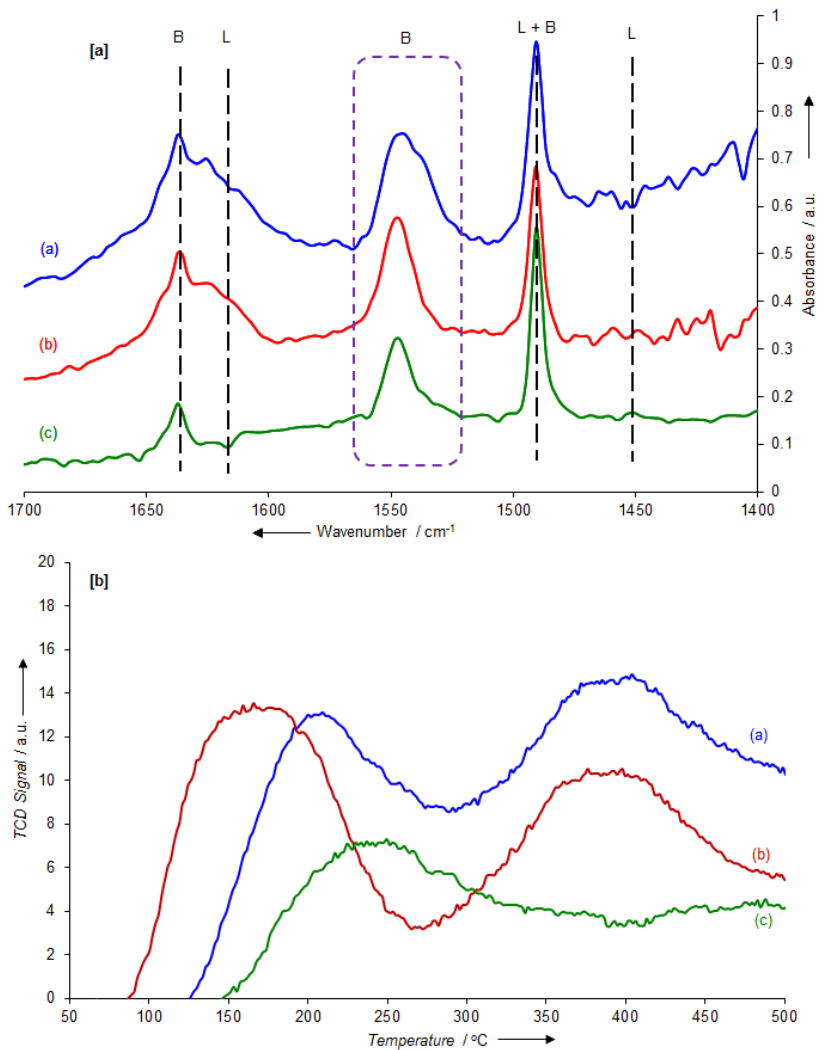

DRIFTS spectra of both catalysts at $300^{\circ} \mathrm{C}$ show the presence of strong Brønsted acid sites ( 1545-1550 $\left.\mathrm{cm}^{-1}\right)$. Although there are very few differences between fresh ABZ-5 and H-ZSM-5, one noticeable difference is a new shoulder that corresponds to a Brønsted acid site at $1540 \mathrm{~cm}^{-1}$ in the case of ABZ-5. This shoulder is apart from the main peak at $1547 \mathrm{~cm}^{-1}$, which must have been generated due to the grafting of $\mathrm{AlBr}_{3}$ on $\mathrm{H}-\mathrm{ZSM}-5$. Also, the Brønsted ("B") acid sites appeared to be stable at high temperatures, although the concentration of Lewis acid sites decreased with increasing temperatures (Figure S5, SI). Acid catalysts having peaks in the same range of wavenumbers are reported to be solid superacids [18]. The spent ABZ-5 catalyst shows significantly lower intense peaks, indicating either a loss of acid sites or lack of access to the acid sites. Figure $\mathrm{S} 7$ (SI) shows that $\mathrm{H}-\mathrm{ZSM}-5$ maintains acid sites up to at least $400^{\circ} \mathrm{C}$, and it is unlikely that there is a loss of Brønsted acid sites from this zeolite. Table S1 (SI) shows that there is some bromine loss during the reaction, but at least the Brønsted sites due to zeolite should remain because they are stable. The presence of coke on the spent catalyst, as indicated by the decrease in TOF with time (Table 2), is likely responsible for blocking access to the acid sites. Acidity of both ABZ-5 and H-ZSM- 5 was also characterized using $\mathrm{NH}_{3}$-TPD. Figure $2 \mathrm{~b}$ shows the results. Both catalysts show two principal peaks, one at $\sim 150-200{ }^{\circ} \mathrm{C}$ that can be characterized as a low temperature (LT) or weakly bound ammonia site ${ }^{[19]}$, and the second one, at $~ 370-400{ }^{\circ} \mathrm{C}$, attributable to a high temperature $(\mathrm{HT})$ or strongly bound ammonia site ${ }^{[19]}$, which probably is able to protonate $\mathrm{NH}_{3}$ to form $\mathrm{NH}_{4}{ }^{+}$. Similar TPD peaks were also observed when $\mathrm{AlCl}_{3}$ was grafted on mesoporous MCM-41 zeolites ${ }^{[20]}$. The low temperature peaks are often identified as ammonia adsorbed through hydrogen co-ordinate bond [19b]. The literature suggests that this weak acidity has little catalytic significance ${ }^{[21]}$. In the case of ABZ5, both the LT and HT peaks are present but shifted to temperatures higher than $\mathrm{H}-\mathrm{ZSM}-5$. The LT, weak acid peak for ABZ-5 is centered at $\sim 210^{\circ} \mathrm{C}$ compared to $\sim 165^{\circ} \mathrm{C}$ for $\mathrm{H}-\mathrm{ZSM}-5$. The HT, strong acid peaks are very similar: $\sim 400^{\circ} \mathrm{C}$ for $\mathrm{ABZ}-5$ compared to $\sim 390^{\circ} \mathrm{C}$ for $\mathrm{H}-\mathrm{ZSM}-5$. Both peak shifts, and the total acidity, as measured by the areas under the $\mathrm{NH}_{3}$-TPD curves, clearly indicate an increase in acidic strength due to the presence of $\mathrm{AlBr}_{3}{ }^{[22]}$. Note that the difference in total acidity between ABZ5 and $\mathrm{H}-\mathrm{ZSM}-5$ is almost entirely due to that of the strong, HT acidity, even though the acid strength, as measured by the shift in the peak temperature, is comparable $\left(\sim 10^{\circ} \mathrm{C}\right.$ shift for HT peak). For spent catalyst, $\mathrm{NH}_{3}$-TPD also showed significantly fewer acid sites and the loss was seen in both the LT and HT regions. Table 3 shows that $A B Z-5$ clearly has more acid sites, which can be attributed to the $\mathrm{AlBr}_{3}$ grafting, which generated new acid sites in the H-ZSM-5. The spent ABZ-5 catalyst on the other hand, did show a loss in number of acid sites (Figure $2[b]$ and Table 3 ). This could either be due to the loss of $\mathrm{Br}$ from ABZ-5 during reaction or due to lack of access to the acid sites from coke.

\begin{tabular}{cc}
$\begin{array}{c}\text { Table 3: Amount of acid sites on zeolite catalysts using } \mathrm{NH}_{3}-\mathrm{TPD} \\
\text { Conc. of acid sites } \\
\text { (mmol/g) }\end{array}$ \\
\hline H-ZSM-5 & 1.19 \\
ABZ-5 (fresh) & 1.55 \\
ABZ-5 (spent) & 0.85
\end{tabular}

\section{Effect of temperature}

Reactions were run on ABZ-5 at three temperatures from 200 to $400{ }^{\circ} \mathrm{C}$. The effect of temperature on $\mathrm{CH}_{4}$ oligomerization is shown in Table 4. ABZ-5 showed activity at each temperature. Higher temperatures $\left(400{ }^{\circ} \mathrm{C}\right)$ resulted in higher rate, as measured by TOF. There is a general increase in total selectivity to aromatics with temperature, with toluene selectivity being the only clear trend with temperature. These aromatic products are thought to be precursors for polynuclear aromatic compounds and coke. Formation of these products at a faster rate at higher temperatures likely leads to faster deactivation. Similar deactivation is also typically observed in methane aromatization [23].

Table 4: Effect of temperature on methane oligomerization over ABZ-5 catalyst $\left(1 \mathrm{~atm}, 9 \mathrm{~L} \mathrm{gcat}^{-1} \mathrm{~h}^{-1}\right) .(-)=$ not detected; measured at $1 \mathrm{hr}$

\begin{tabular}{cccccccccc} 
Temp. & TOF & \multicolumn{1}{c}{ Product selectivity (\%) } \\
\cline { 3 - 10 }$\left({ }^{\circ} \mathrm{C}\right)$ & $\left(\mathrm{h}^{-1}\right)$ & $\mathrm{C}_{2=}$ & $\mathrm{C}_{3}$ & $\mathrm{C}_{4}$ & $\mathrm{~B}$ & $\mathrm{~T}$ & $\mathrm{~EB}$ & $\mathrm{X}$ & $\mathrm{M}^{[\mathrm{a}]}$ \\
\hline
\end{tabular}


$(\mathrm{o}, \mathrm{m}, \mathrm{p})$

\begin{tabular}{cccccccccc}
\hline 200 & 0.01 & 17.6 & 30.4 & 10.7 & 31.6 & 9.7 & - & - & - \\
300 & 0.1 & 3 & 7.9 & 2.3 & 0.49 & 18.6 & 59.6 & 8.1 & - \\
400 & 0.08 & 7.8 & 14.4 & 1.4 & 9.0 & 35.6 & 24.7 & 7.1 & - \\
\hline
\end{tabular}

[a] Mesitylene

\section{Effect of space velocity}

Space velocity (SV) significantly affects hydrocarbon selectivity. ABZ-5 was studied at three different space velocities (3.6, 9 and $\left.18 \mathrm{~L} \mathrm{~g}_{\mathrm{cat}}{ }^{-1} \mathrm{~h}^{-1}\right)$. The corresponding activity results are presented in Table 5. The total aromatic selectivity is relatively high at all conditions tested here, consistent with coke formation. TOF increases at lower SV, as expected. However, there is no clear trend of total aromatic selectivity with SV, nor with any specific aromatic compounds. The only clear trend in selectivity is that of propane selectivity, which increases with increasing SV, indicating that propane is an intermediate. However, there is no obvious relationship between propane and any measurable aromatics.

Table 5: Effect of space velocity on methane oligomerization over ABZ-5 catalyst $\left(1 \mathrm{~atm}, 300^{\circ} \mathrm{C}\right)$. Samples are taken at $1 \mathrm{hr}$ time on stream Space Product selectivity (\%)

\begin{tabular}{cccccccccc}
$\begin{array}{c}\text { Space } \\
\text { Velocity } \\
\left(\mathbf{L} \mathbf{g}_{\text {cat }}{ }^{-1}\right. \\
\left.\mathbf{h}^{-1}\right)\end{array}$ & $\begin{array}{c}\text { TOF } \\
\left(\mathbf{h}^{-1}\right)\end{array}$ & $\mathbf{C}_{2=}$ & $\mathbf{C}_{3}$ & $\mathbf{C}_{4}$ & $\mathbf{B}$ & $\mathbf{T}$ & $\mathbf{E B}$ & $\begin{array}{c}\mathbf{X} \\
(\mathbf{0 , m}, \mathbf{p})\end{array}$ & $\mathbf{M}$ \\
\hline $\mathbf{3 . 6}$ & 0.16 & 4.2 & 0.75 & 2.1 & 1.97 & 8.4 & 20.1 & 5.6 & 56.9 \\
$\mathbf{9}$ & 0.1 & 3 & 7.9 & 2.3 & 0.49 & 18.6 & 59.6 & 8.1 & - \\
$\mathbf{1 8}$ & 0.02 & 17 & 25.6 & 5.5 & 4.6 & 17.1 & 30.2 & - & - \\
\hline
\end{tabular}

TPO

Results in Tables 2, 4, and 5 clearly show the relatively high total selectivity to aromatics. Figure 3 compares the amount and reactivity of coke analyzed in the four catalysts of interest here: fresh catalyst and spent catalysts after being run at three reaction temperatures $\left(200^{\circ} \mathrm{C}, 300^{\circ} \mathrm{C}\right.$, and $\left.400^{\circ} \mathrm{C}\right)$. Peak TPO positions were similar for all runs, $\sim 420^{\circ} \mathrm{C}$, indicating amorphous carbon on the surface of all three spent catalysts ${ }^{[24]}$. TPO results (Table 6 ) show slightly different levels of coke deposition depending on reaction temperature.

Table 6: Carbon deposition from oligomerization reactions

\begin{tabular}{cc} 
Catalyst & $\begin{array}{c}\text { Carbon deposited } \\
(\mathbf{m m o l} / \mathbf{g})\end{array}$ \\
\hline $\begin{array}{l}\text { Fresh ABZ-5 } \\
\text { Spent ABZ-5 }\end{array}$ & 2.53 \\
$\begin{array}{c}\left.\text { (after } 16 \text { hrs reaction at } 200^{\circ} \mathrm{C}\right) \\
\text { Spent ABZ-5 }\end{array}$ & 3.00 \\
$\left(\right.$ after 16 hrs reaction at $\left.300^{\circ} \mathrm{C}\right)$ \\
$\quad$ Spent ABZ-5 \\
(after 16 hrs reaction at $\left.400^{\circ} \mathrm{C}\right)$
\end{tabular}

TPO results for the $300^{\circ} \mathrm{C}$ catalyst show a small peak at $\sim 120^{\circ} \mathrm{C}$ that is not shown in the others. In addition, there is more coke at the $420^{\circ} \mathrm{C}$ peak than the other two runs. This is perhaps consistent with greater aromatic selectivity and TOF for the $300^{\circ} \mathrm{C}$ catalyst (Table 4). [The anomalous TPO peak at $\sim 120^{\circ} \mathrm{C}$ for the fresh catalyst may be due to trace amounts of $\mathrm{CO}_{2}$ adsorbed in handling].

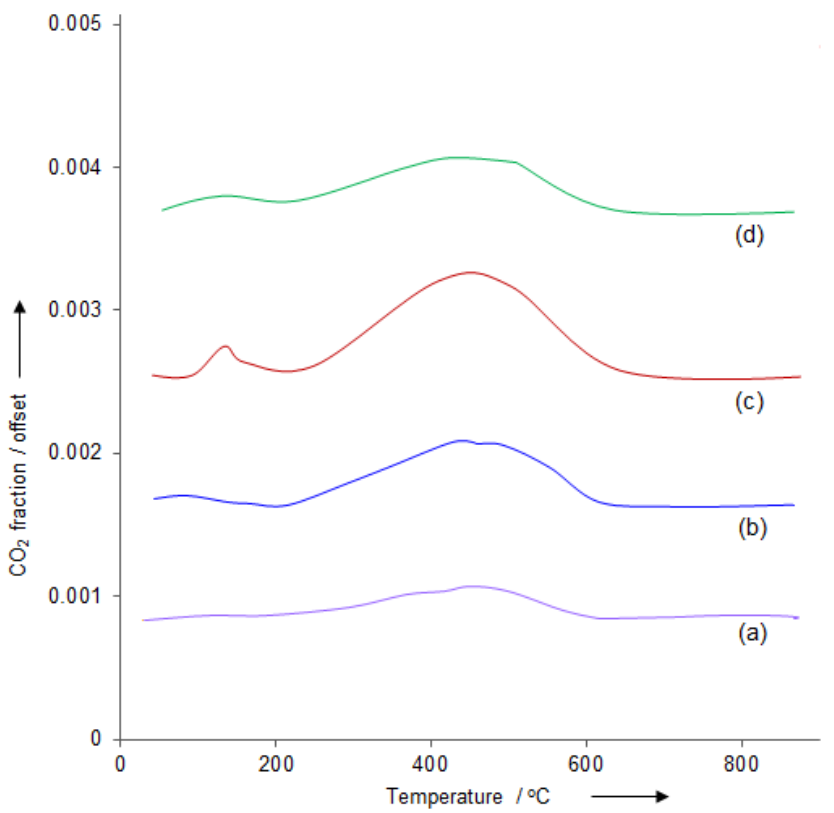

Figure 3: TPO comparison for ABZ-5 after $\mathrm{CH}_{4}$ oligomerization runs (1 atm, 9 $\mathrm{L} \mathrm{gcat}^{-1} \mathrm{~h}^{-1}$ ) at various temperatures on ABZ-5 catalyst (a) fresh catalyst, (b) 200 ${ }^{\circ} \mathrm{C}$, (c) $300{ }^{\circ} \mathrm{C}$, (d) $400{ }^{\circ} \mathrm{C}$ (after running reaction at respective temperatures for $\sim 1000 \mathrm{~min}$ ).

\section{Conclusions}

Vapor grafted $\mathrm{AlBr}_{3}$ on to $\mathrm{H}-\mathrm{ZSM}-5$ has been used to synthesize $\mathrm{AlBr} \times \mathrm{H}$-ZSM-5 catalyst ("ABZ-5"). Grafting of $\mathrm{AlBr}_{3}$ creates new Brønsted acid sites in the H-ZSM- 5 framework, as observed from the $\mathrm{NH}_{3}$-TPD and pyridine-DRIFTS. These acid sites, in synergy with the existing acid sites from the H-ZSM- 5 framework, are likely the cause for the protonation of methane via an oligocondensation mechanism [9], producing higher hydrocarbons. This catalyst has been shown to be active in the oligomerization of methane at temperatures as low as $200^{\circ} \mathrm{C}$.

\section{Experimental Section}

\section{Materials}

$\mathrm{AlBr}_{3}$ (anhydrous, 98\%) and $\mathrm{NH}_{4}-\mathrm{ZSM}-5\left(\mathrm{SiO}_{2} / \mathrm{Al}_{2} \mathrm{O}_{3}=50: 1\right)$ were purchased from Alfa Aesar. $\mathrm{SiO}_{2}$ gel was purchased from $\mathrm{PQ}$ Corporation. $\mathrm{Zr}(\mathrm{OH})_{4}(97 \%)$ was purchased from Sigma Aldrich Inc. and $\mathrm{H}_{2} \mathrm{SO}_{4}$ (95$98 \%$ ) was purchased from Malinckrodt Chemicals Inc. Silver Nitrate $\left(\mathrm{AgNO}_{3}\right), 0.0141 \mathrm{~N}$ solution was purchased as is from Macron Fine Chemicals. Pyridine (50 ppm) in gas phase (balance Argon) was purchased from Praxair Inc. $10 \% \mathrm{NH}_{3} / \mathrm{He}$ (ultra-high purity), $10 \% \mathrm{CH}_{4} / \mathrm{Ar}$ (ultra-high purity) were purchased from Airgas Inc.

\section{Catalyst Preparation}

ABZ-5 was prepared as follows: $\mathrm{H}-\mathrm{ZSM}-5$ was prepared by calcining $\mathrm{NH}_{4}$ $\mathrm{ZSM}-5$ at $500{ }^{\circ} \mathrm{C}$ for $3 \mathrm{~h}$ in a muffle furnace. In order to optimize the $-\mathrm{OH}$ 
concentration on the surface of the as-prepared $\mathrm{H}-\mathrm{ZSM}-5$, it was washed in three alternate cycles of $\mathrm{HBr}(1 \mathrm{M})$ and deionized water and then dried in a vacuum at $80{ }^{\circ} \mathrm{C}$ for $72 \mathrm{~h}$ before being exposed to the room atmosphere ${ }^{[25]}$.

Then, in separate vials, $\mathrm{AlBr}_{3}(1 \mathrm{~g})$ and the washed $\mathrm{H}-\mathrm{ZSM}-5(1 \mathrm{~g})$ were loaded into a Teflon lined SS autoclave (Parr Instruments Inc., Moline, IL) inside a glovebox. The autoclave was then sealed and put inside an isothermal oven at $180{ }^{\circ} \mathrm{C}$ for $72 \mathrm{~h}$ in order for $\mathrm{AlBr}_{3}$ to vaporize and react with the hydroxyl groups on the surface of the zeolite. The excess pressure generated during the synthesis ( $\mathrm{HBr}$ formation) was released by opening the autoclave in a fume hood. The autoclave was then returned to the glovebox where the catalyst was recovered. Masses of all the materials were recorded in order to check for the weight gain by the H-ZSM- 5 sample. ABSi catalyst was also prepared using the same methodology, but substituting the $\mathrm{H}-\mathrm{ZSM}-5$ for the $\mathrm{SiO}_{2}$ gel.

Sulfated zirconia (SZ) was prepared using a previously reported literature procedure ${ }^{[26]}$. Briefly, $\mathrm{Zr}(\mathrm{OH})_{4}$ gel was washed with $\mathrm{H}_{2} \mathrm{SO}_{4}(0.5$ $\mathrm{M})$ solution and the washed product was dried at $110^{\circ} \mathrm{C}$ overnight in an isothermal oven. Then the material was subsequently heated to $550{ }^{\circ} \mathrm{C}$ at a ramp rate of $5{ }^{\circ} \mathrm{C} \mathrm{min}^{-1}$ and calcined at this temperature for $4 \mathrm{~h}$ under static air. The solid sulfated zirconia powder obtained was then stored for further use. Formation of sulfated zirconia was confirmed by XRD on the prepared sample, which showed a diffraction pattern similar to that previously reported ${ }^{[26]}$.

\section{Ammonia-TPD}

Ammonia-TPD was carried out using AMI-200 reactor system (Altamira Instruments Inc. Pittsburgh, PA) in conjunction with an Ametek LC-D Mass Spectrometer. Typically $25 \mathrm{mg}$ of catalyst was weighed and loaded in a quartz tube reactor. The catalyst was pretreated at $100^{\circ} \mathrm{C}$ for $30 \mathrm{~min}$ under He flow to clean the catalyst surface. After pretreatment, the sample was cooled down to $50{ }^{\circ} \mathrm{C}$, and ammonia was adsorbed by flowing it through the catalyst bed for $1 \mathrm{~h}$. After ammonia adsorption, $25 \mathrm{ml} \mathrm{min}^{-1}$ of He was flowed for $40 \mathrm{~min}$ to remove any physisorbed/residual ammonia. Then, the Mass Spectrometer and TCD detectors were turned on and the temperature was ramped up at $10^{\circ} \mathrm{C} \mathrm{min}^{-1}$ from $50{ }^{\circ} \mathrm{C}$ to $500^{\circ} \mathrm{C}$. Masses that were analyzed included $16\left(\mathrm{NH}_{3}\right), 17\left(\mathrm{NH}_{3}\right), 18\left(\mathrm{H}_{2} \mathrm{O}\right), 81(\mathrm{HBr})$

\section{Pyridine-DRIFTS}

DRIFTS experiments using pyridine as a probe molecule were carried out using Thermo Scientific Nicolet 6700 FTIR equipped with Harrick Praying Mantis reaction cell fitted with $\mathrm{KBr}$ windows. Spectra of all the samples were recorded with a spectral resolution of $4 \mathrm{~cm}^{-1}$ in region going from $4000-650 \mathrm{~cm}^{-1}$. In a typical experiment, the IR cell was loaded with the catalyst sample inside the glovebox. The sample was then transferred to the spectrometer and pretreated at $100{ }^{\circ} \mathrm{C}$ for $30 \mathrm{~min}$. under He flow (30 $\mathrm{sccm}$ ) to clean surface of the catalyst. After pretreatment, the sample was cooled down to $25^{\circ} \mathrm{C}$ and a background spectrum was recorded. At this temperature, catalyst was saturated with pyridine vapors for $45 \mathrm{~min}$. The saturated sample was then treated under He flow for $30 \mathrm{~min}$. Sample was then treated at $100{ }^{\circ} \mathrm{C}$ for $10 \mathrm{~min}$ and cooled to room temperature and the actual spectrum was recorded. Similar spectra were recorded at room temperature after $10 \mathrm{~min}$. treatments were carried out at $200{ }^{\circ} \mathrm{C}, 300{ }^{\circ} \mathrm{C}$, and $400^{\circ} \mathrm{C}$ to check the thermal stability of the acid sites on catalysts.

FTIR of hydroxyl region was carried out in the same aforementioned DRIFTS cell under Helium flow and at various temperatures. Some IR catalyst samples were also recorded using Bruker Alpha IR spectrometer using Diamond ATR crystal in the range of $4000-400 \mathrm{~cm}^{-1}$.

\section{TPO}

Temperature programmed oxidation (TPO) experiments were carried out in an Altamira AMI-200 catalyst characterization system in conjunction with Ametek Dycor Quadlink residual gas analyzer. Typically, $30 \mathrm{mg}$ of spent catalyst was loaded in the reactor tube and the temperature was ramped up from $30{ }^{\circ} \mathrm{C}$ to $900{ }^{\circ} \mathrm{C}$ at a rate of $10 \mathrm{~K} \mathrm{~min}^{-1}$ under a flow of $10 \% \mathrm{O}_{2} / \mathrm{He}$. Masses $(\mathrm{m} / \mathrm{z})$ that were analyzed for this procedure included $44\left(\mathrm{CO}_{2}\right), 28$ (CO), $18\left(\mathrm{H}_{2} \mathrm{O}\right), 32\left(\mathrm{O}_{2}\right), 4$ (Helium).

\section{XRD}

X-ray diffraction studies were conducted at Shared Instrument Facility (SIF) at LSU using PAN Analytical EMPYREAN diffractometer with a generator voltage of $45 \mathrm{mV}$ and a tube current of $40 \mathrm{~mA}$. The scan range chosen was from 5 to $90^{\circ}$ at a step size of 0.02626 .

\section{XPS}

XPS analysis of all the samples was carried out using ScientaOmicron ESCA 2SR XPS/Auger instrument at Shared Instrument Facility (SIF) at LSU. All the samples were ran at a characteristic energy of $1486.7 \mathrm{eV}$ and with an acquisition time of $2 \mathrm{~s}$.

\section{Reaction Studies}

$\mathrm{CH}_{4}$ oligomerization was carried out in a custom built reactor equipped with a Hamilton $1 / 4$ " OD glass lined SS tube. Typically, the supported catalyst $(0.10 \mathrm{~g})$ was loaded into the reactor tube and was heated to the desired reaction temperature at which time methane was passed over the catalyst. Downstream of the reactor, a caustic wash tank was fitted (aq. $\mathrm{KOH}, 0.1$ $\mathrm{N}$ ) to neutralize $\mathrm{HBr}$ (when used) during the treatment of the catalyst. Products were analyzed using Shimadzu GC2014 (FID) equipped with Restek RT-Q-Bond column (30 m x $0.53 \mathrm{~mm} \times 20 \mu \mathrm{m}$ ). A schematic could be found in Figure S1, SI. Downstream of the reactor the outlet line going to the GC (for analysis), was not heated because we didn't observe any condensation as analytes of interest were few ppm.

\section{Silver nitrate $\left(\mathrm{AgNO}_{3}\right)$ test}

$\mathrm{AgNO}_{3}$ is a common test for identifying halide ions and can also be used to quantify the amount of halides present in a sample. This test was used in the estimation of bromine $(\mathrm{Br})$ content as well as to confirm the presence of bromide ions in the $\mathrm{HBr}$ dissolved aqueous sample. In a typical test, measured amount of catalyst $(0.2 \mathrm{~g})$ was dissolved in water (although its moisture sensitive, here only dissolution of bromide ions in the aqueous phase was desired), then using $1 \mathrm{M}$ potassium chromate $\left(\mathrm{K}_{2} \mathrm{CrO}_{4}\right)$ indicator solution, it was titrated against $0.0141 \mathrm{~N}$ silver nitrate to the reddish-brown endpoint. For the $\mathrm{HBr}$ dissolved water samples, it was directly titrated with silver nitrate solution using potassium chromate indicator solution.

\section{Acknowledgements}


Authors would like to thank Chevron for Chevron Innovation Research Fund, LSU ORED (Office of Research and Economic Development) and NSF EAGER grant (\# 1644895)

\section{Conflict of interest}

\section{The authors declare no conflict of interest}

Keywords: natural gas • oligomerization $\bullet$ superacidic systems

[1] a) S. Jenner, A. J. Lamadrid, Energ. Policy 2013, 53, 442-453; b) Q. Wang, X. Chen, A. N. Jha, H. Rogers, Renew. Sust. Energ. Rev. 2014, 30, 1 28; cT. Boersma, C. Johnson, Rev. Policy Res. 2012, 29, 570-576.

[2] S. J. Blanksby, G. B. Ellison, Acc. Chem. Res. 2003, 36, 255-263.

[3] G. E. Keller, M. M. Bhasin, J. Catal. 1982, 73, 9-19.

[4] N. Kumar, Z. Wang, S. Kanitkar, J. J. Spivey, App. Pet. Res. 2016, 1-7.

[5] Q. Zhu, S. L. Wegener, C. Xie, O. Uche, M. Neurock, T. J. Marks, Nat. Chem. 2013, 5, 104-109.

[6] A. Zhang, S. Sun, Z. J. A. Komon, N. Osterwalder, S. Gadewar, P. Stoimenov, D. J. Auerbach, G. D. Stucky, E. W. McFarland, Phys. Chem. Chem. Phys. 2011, 13, 2550-2555.

[7] X. Guo, G. Fang, G. Li, H. Ma, H. Fan, L. Yu, C. Ma, X. Wu, D. Deng, M. Wei, D. Tan, R. Si, S. Zhang, J. Li, L. Sun, Z. Tang, X. Pan, X. Bao, Science 2014, 344, 616-619.

[8] a) Y. Wu, L. Emdadi, Z. Wang, W. Fan, D. Liu, App. Cat. A: Genera/2014, 470, 344-354; b) S. Ma, X. Guo, L. Zhao, S. Scott, X. Bao, J. Energ. Chem. 2013, 22, 1-20; c) P. Schwach, X. Pan, X. Bao, Chem. Rev. 2017, 117, 84978520; d) K. Sun, D. M. Ginosar, T. He, Y. Zhang, M. Fan, R. Chen, Ind. Eng. Chem. Res. 2018, 57, 1768-1789.

[9] G. A. Olah, G. Klopman, R. H. Schlosberg, J. Amer. Chem. Soc. 1969, 91, 3261-3268.

[10] G. A. Olah, Y. Halpern, J. Shen, Y. K. Mo, J. Amer. Chem. Soc. 1973, 95, 4960-4970.

[11] a) G. A. Olah, R. H. Schlosberg, J. Amer. Chem. Soc. 1968, 90, 27262727 ; b) S. Vasireddy, S. Ganguly, J. Sauer, W. Cook, J. J. Spivey, Chem. Comm. 2011, 47, 785-787.

[12] a) W. Hua, A. Goeppert, J. Sommer, App. Catal. A: General 2001, 219, 201-207; b) S. Rezgui, A. Liang, T. K. Cheung, B. C. Gates, Catal. Lett. 1998 , $53,1-2$.

[13] D. Farcasiu, S. L. Fisk, M. T. Melchior, K. D. Rose, J. Org. Chem. 1982, 47, 453-457.

[14] a) J. D. Heldman, J. Amer. Chem. Soc. 1944, 66, 1791-1793; b) J. M. Crafts, C. Friedel, J. Amer. Chem. Soc. 1877, 32, 725-791; c) A. Corma, H. García, Chem. Rev. 2003, 103, 4307-4366.

[15] a) A. L. Glasebrook, N. E. Phillips, W. G. Lovell, J. Amer. Chem. Soc. 1936, 58, 1944-1948; b) O. Grummitt, E. E. Sensel, W. R. Smith, R. E. Burk, H. P. Lankelma, J. Amer. Chem. Soc. 1945, 67, 910-914.

[16] R. L. Martins, M. Schmal, App. Catal. A: General 2006, 308, 143-152.

[17] W. Hua, A. Goeppert, J. Sommer, App. Catal. A: General 2001, 219, 201207.

[18] a) W.-H. Chen, H.-H. Ko, A. Sakthivel, S.-J. Huang, S.-H. Liu, A.-Y. Lo, T.-C. Tsai, S.-B. Liu, Catal. Today 2006, 116, 111-120; b) R. Buzzoni, S. Bordiga, G. Ricchiardi, C. Lamberti, A. Zecchina, G. Bellussi, Langmuir 1996, 12, 930-940; c) Y. Wu, L. Qin, G. Zhang, L. Chen, X. Guo, M. Liu, Ind. Eng. Chem. Res. 2013, 52, 16698-16708; d) M. Marczewski, H. Marczewska, K. Witosławski, J. Mol.Catal. A: Chemical 1995, 97, 101-110; e) H. Hattori, O. Takahashi, M. Takagi, K. Tanabe, J. Catal. 1981, 68, 132-143.

[19] a) L. Rodríguez-González, F. Hermes, M. Bertmer, E. RodríguezCastellón, A. Jiménez-López, U. Simon, App. Catal. A: General 2007, 328, 174-
182; b) A. S. Al-Dughaither, H. de Lasa, Ind. Eng. Chem. Res. 2014, 53, 1530315316.

[20] D. Dubé, S. Royer, D. Trong On, F. Béland, S. Kaliaguine, Micro. Meso. Mater. 2005, 79, 137-144.

[21] a) N. Katada, H. Igi, J. H. Kim, M. Niwa, J. Phys. Chem. B 1997, 5647, 5969; b) N. Katada, M. Niwa, Catal. Surv. Asia 2004, 8, 161.

[22] H. Xiao, J. Zhang, X. Wang, Q. Zhang, H. Xie, Y. Han, Y. Tan, Catal. Sci. Tech. 2015, 5, 4081-4090.

[23] Z. R. Ismagilov, E. V. Matus, L. T. Tsikoza, Energ. Env. Sci. 2008, 1, 526541.

[24] C. A. Querini, in Catalysis: Volume 17, Vol. 17 (Eds.: J. J. Spivey, G. W. Roberts), The Royal Society of Chemistry, UK, 2004, pp. 166-209.

[25] R. S. Drago, S. C. Petrosius, C. W. Chronister, Inorg. Chem. 1994, 33 367-372.

[26] K. M. Arata, H., Solid Superacids, Nova Science Publishers, New York, 2011. 


\section{FULL PAPER}

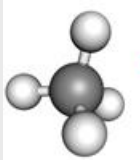

$\mathrm{CH}_{4}$
Superacid catalyst $200-400^{\circ} \mathrm{C}$

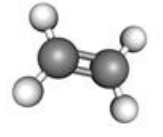

Ethylene

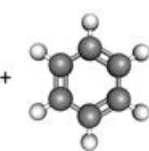

Benzene

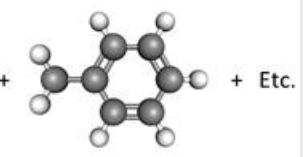

Toluene
Superacid catalyst for methane conversion: Methane can be activated through variety of ways including use of oxidants, without oxidants. Superacidic systems possess high enough acidity to protonate methane and start oligomerization of it through oligo-condensation mechanism. Products can include $\mathrm{C}_{2}, \mathrm{C}_{3}$ feedstocks as well as aromatics.
Swarom Kanitkar, James Carter, Graham Hutchings*, Kunlun Ding, James J. Spivey*

Page No. - Page No.

Low Temperature Direct Conversion of Methane using a Solid Superacid 